
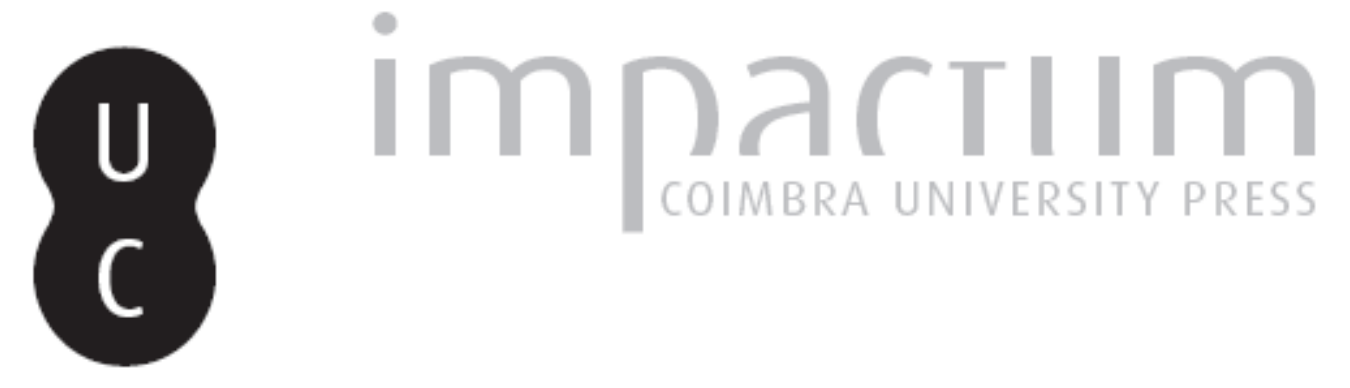

\title{
Uma alquimia poética diversa: apontamentos à margem da edição crítica de André Falcão de Resende
}

Autor(es): $\quad$ Spaggiari, Barbara

Publicado por: Imprensa da Universidade de Coimbra

URL persistente:

URI:http://hdl.handle.net/10316.2/42446

DOI:

DOl:https://doi.org/10.14195/0870-8584_0_3

Accessed : $\quad$ 26-Apr-2023 15:22:20

A navegação consulta e descarregamento dos títulos inseridos nas Bibliotecas Digitais UC Digitalis, UC Pombalina e UC Impactum, pressupõem a aceitação plena e sem reservas dos Termos e Condições de Uso destas Bibliotecas Digitais, disponíveis em https://digitalis.uc.pt/pt-pt/termos.

Conforme exposto nos referidos Termos e Condições de Uso, o descarregamento de títulos de acesso restrito requer uma licença válida de autorização devendo o utilizador aceder ao(s) documento(s) a partir de um endereço de IP da instituição detentora da supramencionada licença.

Ao utilizador é apenas permitido o descarregamento para uso pessoal, pelo que o emprego do(s) título(s) descarregado(s) para outro fim, designadamente comercial, carece de autorização do respetivo autor ou editor da obra.

Na medida em que todas as obras da UC Digitalis se encontram protegidas pelo Código do Direito de Autor e Direitos Conexos e demais legislação aplicável, toda a cópia, parcial ou total, deste documento, nos casos em que é legalmente admitida, deverá conter ou fazer-se acompanhar por este aviso.

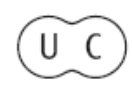




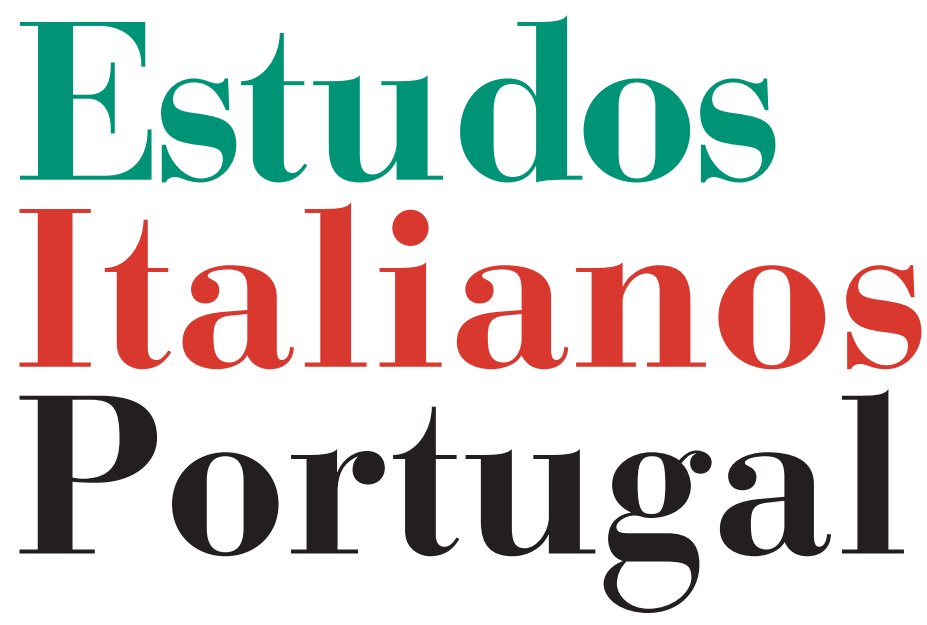

Instituto

Italiano

de Cultura

de Lisboa

Nova Série

$\mathrm{N}^{\mathbf{0}} \mathbf{0}$ 
UMA ALQUIMIA POÉTICA DIVERSA. APONTAMENTOS À MAR GEM DA EDIÇÃO CRÍTICA DE ANDRÉ FALCÃO DE RESENDE

\section{BArbara Spaggiari}

Na lírica PORTUguesa de Quinhentos, move-se, em torno de Camões, uma nebulosa de poetas menores, designados, de forma não unívoca e em termos genéricos, como "líricos camonianos" (Teófilo Braga), ou, então, como "poetas maneiristas" (Aguiar e Silva). A primeira definição mostra-se ineficaz, e até incorrecta, na medida em que estes poetas não se podem considerar simples imitadores de Camões, mas, antes, seus contemporâneos; ${ }^{1}$ por outro lado, a etiqueta de "maneirista" reflecte mais uma atitude mental, do que uma verdadeira inserção numa corrente literária, ainda que alguns temas e traços estilísticos sejam comuns entre os poetas da época. ${ }^{2}$

No âmbito da experiência lírica de Quinhentos, outra perspectiva surge, susceptível de dilucidar o quadro a partir de

1 A presunta imitação de Camões, como aponta lucidamente Jorge de Sena, depende do facto deles "participarem da mesma atmosfera espiritual e cultural, de viverem a mesma crise de valores religiosos e morais».

2 Falo, nomeadamente, no recurso assíduo a motivos quais «a angústia vital e o sentimento de crise, a obsessão do tempo destruidor, a aniquilação da experiência terrena, o engano e a ilusão da existência, a melancolia, o motivo do mundo desconcertado, as contradições íntimas do homem (...), donde resulta uma concordia discors que reflecte a própria estrutura do mundo, concetti e metáforas preciosistas, hipérboles e paradoxos, adynata e complicações sintácticas que exprimem o desequilíbrio interior» (Aguiar e Silva). 
um outro ponto de vista. Conforme é bem sabido, o séc. XVI é travejado por um fenómeno geral, que abrange a lírica europeia no seu conjunto, o do petrarquismo. ${ }^{3}$ Mas, concomitantemente, e com ele mantendo, em parte, relações antitéticas, vigora uma corrente literária de cunho classicista, que retoma a herança dos humanistas, para utilizar moldes latinos na composição dos poemas vernaculares.

Nesta corrente se integra um poeta, André Falcão de Resende, cuja obra é, ainda hoje, quase desconhecida: de facto, nunca veio a lume, apesar do seu inegável interesse histórico. $^{4}$

Os precursores deste filão secundário - que não se opõe, mas, de outra forma, prossegue paralelamente ao petrarquismo dominante - são alguns humanistas italianos do século XV, cujas obras saíram do prelo em inícios de Quinhentos, ${ }^{5}$ sendo, pois, contemporâneas das edições aldinas dos clássicos latinos e gregos. ${ }^{6}$

3 O ponto da questão na rica monografia de Rita Marnoto, O Petrarquismo português do Renascimento e do Maneirismo, Coimbra, Por ordem da Universidade, 1997.

${ }^{4}$ As vicissitudes desta obra malfadada vão ser objecto da segunda parte deste ensaio.

5 Baste lembrar as colectâneas de Giovanni Pontano, cujo papel foi importantíssimo no seio da corte de Aragão, em Nápoles, e dentro da Academia que dele tomou o nome. Foi graças a ele, de facto, que a maioria dos géneros poéticos ditos "menores" foram felizmente recuperados da latinidade clássica (Catulo, Propércio, Tibulo). Na sua vastíssima produção, ressaltam, além das seis Eclogae, os poemas juvenis de inspiração elegíaca e epigramática (Amores); os epicédios (Tumuli); as Neniae e os versos Iambici, dedicados ao filho; e, sobretudo, a recolha De amore conjugali.

${ }^{6}$ Foi Aldo Manuzio, não apenas amigo de Poliziano e de Erasmo, mas também frequentador de Bembo, quem organizou e preparou, nos começos do séc. XVI, as grandes edições dos clássicos gregos e latinos. Cabe-lhe o mérito ulterior de ter inventado um novo formato para editar as obras de Dante e Petrarca, a par dos Asolani de Pietro Bembo e da Arcadia de Jacopo Sannazaro, edições que alcançarão um êxito imediato e uma grande difusão na Europa toda. 
A afirmação da imprensa como verdadeira empresa quer comercial, quer cultural, no começo do século XVI, com efeito, permitiu colocar à disposição do público, poucos anos volvidos, edições relativamente económicas dos maiores poetas, tanto clássicos, como italianos, não raro acompanhadas por comentários. ${ }^{7}$ Tendo em vista a experimentação de novas modalidades compositivas, imitam-se, então, pela primeira vez em língua vernácula, formas métricas e géneros poéticos ainda desconhecidos das literaturas românicas, tais como a ode, a elegia, ou a écloga, entre muitos outros. ${ }^{8}$

Na segunda década do século XVI, por conseguinte, encontravam-se reunidas todas as condições para o estabelecimento daquele cânone que devia oferecer aos novos poetas, modelos compositivos a imitar. Foi, como é sabido, o padrão petrarquista elaborado por Bembo que acabou por dominar em toda a Europa. Anunciado pela publicação dos Asolani, em 1505, o projecto poético bembesco foi aperfeiçoado no célebre tratado Prose de la volgar lingua, impresso em 1525. A nova poética, que tinha por eixos o neo-platonismo, pelo que diz respeito à teoria do amor, e o código poético de Petrarca, no plano estilístico-formal, suscitou reacções por parte de uma facção de intelectuais italianos, ainda que minoritária, mesmo antes de terem sido divulgadas, através da imprensa, as próprias rimas de Bembo.

7 Vejam-se Giorgio Montecchi e Antonio Sorella, I nuovi modi della tradizione: la stampa tra Quattro e Cinquecento, in Storia della Letteratutra Italiana, dir. da Enrico Malato (STOLI), Roma, Salerno, vol. X, 2001, pp. 633-673, com a respectiva bibliografia; Nadia Cannata, Il canzoniere a stampa (1470-1530). Tradizione e fortuna di un genere fra storia del libro e letteratura, Roma, Bagatto, 2000 («Filologia materiale», 1).

8 Sobre a introdução dos géneros poéticos "menores" na literatura italiana de Quinhentos, vejam-se, entre outros, Roberto Fedi, La fondazione dei modelli nel Cinquecento, in STOLI IV, pp. 507 ss. e Giorgio Patrizi, La nascita delle poetiche, in Manuale di letteratura italiana. Storia per generi e problemi, a c. di G. Brioschi-Costanzo Di Girolamo, Torino, Bollati-Boringhieri, 1994, vol. II, pp. 627-658. 
A chamada "questão da língua" foi, além do mais, uma questão de modelos poéticos a imitar. Contra a hegemonia de Petrarca, tal como a preconizava Bembo nos seus escritos, tomaram posição, desde logo, alguns letrados do mesmo círculo véneto a que pertencia o cardeal, a saber, Gian Giorgio Trissino e Antonio Brocardo. A polémica inflamou-se, até que desaguou na publicação, quase contemporânea, das rimas dos principais protagonistas daquela diatriba. Começou Trissino, em 1529, com as suas Rimas, publicadas em Vicenza, a quem replicou Bembo, no ano sucessivo, com as próprias Rimas, impressas em Veneza.

O ano 'fatal' de 1530 marca uma viragem decisiva na evolução da lírica europeia. ${ }^{9}$ Nesse ano, de facto, vêm a lume, juntamente com as Rime de Bembo e a segunda edição corrigida dos Asolani, outras recolhas autorais de grande impacto, como sejam, as Rime e as Ecloghe piscatorie de Jacopo Sannazaro, ou ainda os Lusus do poeta novilatino Andrea Navagero.

Se, em 1525, Bembo, com as Prose de la volgar lingua, tinha construído a teoria do classicismo vernacular, cinco anos depois, em 1530, a edição das Rime forneceu uma aplicação prática daquela teoria, sancionando a data de nascimento do petrarquismo quinhentista. O sucesso imediato da obra bembesca apagou, subitamente, as veleidades dos adversários.

Só um deles ousou enfrentar a supremacia de Bembo, publicando, com alguma precipitação (sugerida, evidentemente, pelas circunstâncias), a própria recolha de versos: Bernardo Tasso. O seu Libro primo degli Amori saiu, de facto, em 1531, ${ }^{10}$

${ }^{9}$ Veja-se Francesco Erspamer, La svolta del Trenta. Sannazaro e Bembo, in Manuale di letteratura italiana. Storia per generi e problemi, cit., vol. II, pp.193-99.

${ }^{10}$ Um exemplar da "princeps" encontra-se na Biblioteca Nacional de Lisboa (Libro primo de gli amori, 1531: BNL, cota RES. 818//3P). Conservam-se, aliás, nas bibliotecas públicas portuguesas mais algumas obras de Bernardo Tasso, a saber, o poema épico L'Amadigi, 1583 (BNL, cota L. 2265 V); a última e mais completa recolha das Rime, 1560 (BNL, cota L. 4104//P); e, enfim, o epistolário reunido sob o título Le lettere, 1551 (BGUC, cota S.P. Y-10-18). 
com uma introdução em que o autor declara explicitamente o seu propósito de escolher caminhos diversos dos pisados por Petrarca, seguindo, antes, a estrada principal traçada pelos poetas latinos (e gregos). ${ }^{11}$

Malograda a proposta de Trissino, por ser demasiado artificiosa e intelectualista, e tendo o próprio Brocardo falecido nesse mesmo ano de 1531, apenas resta Bernardo Tasso a representar, por aqueles anos cruciais, uma linha poética que, sem rejeitar totalmente a experiência petrarquista, se propõe, contudo, remontar aos autores clássicos, nomeadamente, latinos, seja de forma directa, seja por intermédio dos poetas novilatinos (Pontano e Navagero, especificamente). É, portanto, a sua, uma maneira de reivindicar uma maior liberdade na escolha de modelos, não se limitando ao cânone do petrarquismo lírico, mas situando-se no terreno da latinidade clássica há pouco redescoberta. As inovações introduzidas por Bernardo Tasso, a partir da primeira edição de 1531, ${ }^{12}$ incidem tanto sobre os moldes métricos, como sobre os géneros poéticos.

11 «De' tre miei libri adunque, che tanti appunto sono, intitolati gli Amori, non potendo ora per nove occupazioni fargli tuttatre imprimere, solo in luce ne verrà il primiero $(. . .)^{\circ}$; et hovvi nella fine aggiunto alcune altre poche rime, cantate secondo la via e l'arte degli antiqui boni poeti greci e latini, i quali, sciolti d'ogni obbligazione, cominciavano e fornivano i loro poemi com'a ciascun meglio parea, massimamente quelli che d'amorosi soggetti ragionano, e ch'hanno similitudine co' volgari, como sono epigrammi, ode et elegie» (cf. dedicatória «Alla Signora Genevra Malatesta»). Na segunda edição de 1534, o volume abre com mais uma epístola dedicatória "Al Prencipe de Salerno suo Signore», a saber, don Ferrante Sanseverino, em que Bernardo Tasso se mostra bem ciente da novidade, algo perturbadora, dos seus versos: «Porto fermissima opinione, illustrissimo Signor mio, che la novità de' miei versi, cosa non meno invidiosa che dilettevole, moverà molti a vituperarli: e di questa novella tela altri le fila, altri la testura biasimerà, parendoli forse mal convenirsi alla lingua volgare, posto da canto le Muse toscane, alle greche e alle latine accostarsi, e quelle oltre il loro costume in varie e strane maniere di rime, inni, ode, egloghe e selve, quasi per viva forza costringer a favellare».

12 Duas outras, acrescentadas e corrigidas, saíram em 1534 e 1537, respectivamente (Amori $\left.1531^{1}, 1534^{2}, 1537^{3}\right)$. 
São, precisamente, essas inovações, concentradas nas três primeiras edições das suas rimas, ${ }^{13}$ que se difundiram, não tanto numa Itália subjugada pelo petrarquismo bembesco, como no resto da Europa, nomeadamente, em França, na Espanha e em Portugal. ${ }^{14}$

A difusão de tais novidades, introduzidas por Bernardo Tasso nas literaturas desses países, tem a ver com a actividade do poeta-cortesão, estatuto comum à maioria dos intelectuais da época. Nas várias cortes da Europa, os homens de letras desempenhavam as funções de diplomata, ou secretário particular de reis e príncipes, viajando entre uma e outra capital, e assim iam estabelecendo relações, por vezes de amizade, com os correspondentes letrados estrangeiros.

Por volta de 1530, encontravam-se reunidos, na corte do vice-rei de Nápoles, tanto os membros da Academia a que pertenceram Pontano e Sannazaro, como Bernardo Tasso, na época secretário particular do príncipe Ferrante Sanseverino, e até Garcilaso de la Vega, representante do imperador Carlos V.

Já antes, a partir de 1525, Baldassar Castiglione fizera uma estadia em Espanha, na própria corte imperial, como núncio apostólico, onde preparou a edição do seu célebre tratado Il Cortegiano (1528), impresso pouco antes da sua morte, ocorrida em Toledo, a 8 de Fevereiro de 1529.

${ }^{13}$ Mais em detalhe: Bernardo Tasso compôs as suas Éclogas e Elegias antes de 1534; o Epitalámio em 1532; a Favola di Piramo e Tisbe em 1534; a Favola di Ero $e$ Leandro em 1537. As odas de inspiração horaciana aparecem desde a primeira edição de 1531; os demais géneros de molde clássico fazem parte, como já foi dito, das três primeiras edições dos Amori.

${ }^{14}$ Cf. José da Costa Miranda, Alguns apontamentos para um futuro estudo sobre Bernardo Tasso em Portugal, in "Arquivos do Centro Cultural Português», XIII (1978), pp. 75-104; Barbara Spaggiari, L'«enjambement» di Bernardo Tasso, in «Studi di Filologia Italiana», LII (1994), pp.111-139, e Ead., L'adattamento di metri italiani nella poesia iberica del sec. XVI: l'ode e il sonetto, in "E vós, Tágides minhas». Miscellanea in onore di Luciana Stegagno Picchio, a c. di Maria-José de Lancastre, Silvano Peloso, Ugo Serani, Viareggio-Lucca, Baroni Ed., 1999, pp. 681-689. 
Também em Espanha se encontrava, desde 1525, o poeta novilatino Andrea Navagero, embaixador da República de Veneza; reza a lenda dos seus encontros com Juan Boscán, nos jardins do paço real de Granada, onde o poeta espanhol, futuro editor de Garcilaso de la Vega, teria aprendido, no seu convívio, a compor sonetos. ${ }^{15}$

Quanto a Bernardo Tasso e a Garcilaso de la Vega, aos quais cabe o mérito de terem introduzido, na lírica vernácula, a Canção em forma de lira (ou, mais simplesmente, a Lira), é certo que os dois poetas tiveram ocasião de se cruzarem, e não apenas em Nápoles, mas também aquando do cerco de Cartago e na campanha de Tunes (1535). ${ }^{16}$ Por seu lado, Bernardo Tasso viajou por Espanha, como diplomata, com toda a certeza em 1537, e, talvez, em 1539. ${ }^{17}$

Voltando a Portugal, apenas cabe lembrar a afamada viagem a Itália de Sá de Miranda, entre 1521 a 1526, e só para sublinhar como este evento, longe de ser excepcional, se insere nos hábitos comuns aos letrados da época. Mais do que isso, podemos afirmar que a circulação de intelectuais

15 No ano de 1526, segundo testemunha o próprio Boscán, o embaixador de Veneza teve a oportunidade de conversar com ele sobre poesia e literatura, abrindo caminho para a adopção do hendecassílabo italiano na lírica espanhola. Depois daquele afamadíssimo encontro, Boscán afirmou ter sido «el primero que ha juntado la lengua castellana con el modo de escrivir italiano» (cf. Juan Boscán, Obra completa. Edición de Carlos Clavería, Madrid, Cátedra, 1999, pp. 12 e 17).

${ }^{16}$ Cf. o estudo preliminar de Rafael Lapesa ao volume ${ }^{\circ}$ : Garcilaso de la Vega, Obra poética y textos en prosa. Ed. de Bienvenido Morros., Barcelona, Crítica, 1995 («Biblioteca Clásica»), pp. xxxviii e lii. Um útil resumo sobre as relações pessoais entre Bernardo Tasso e Garcilaso de la Vega pode ler-se em Giovanni Caravaggi, La fortuna di Bernardo Tasso in Spagna, in Tasso e l'Europa. Atti del Convegno Internazionale (IV Centenario della morte del Poeta), Università di Bergamo, 24-25-26 maggio 1995, a c. di Daniele Rota, Viareggio-Lucca, Baroni Editore, 1996, pp. 337-356.

${ }_{17}$ No que concerne à biografia de Bernardo Tasso, a referência fundamental continua a ser a monografia de Edward Williamson, Bernardo Tasso, [Roma, 1951]. Versione ital. di Daniele Rota, Centro di Studi Tassiani, Bergamo, 1993. 
que se encontravam, todos eles, de uma forma ou de outra, ao serviço de reis e príncipes, ia de mãos dadas com a difusão de obras impressas que contemporaneamente era levada a cabo pelas principais tipografias europeias.

Não pretendemos, como tal, negar qualquer importância aos contactos directos entre intelectuais, bem pelo contrário. Mas, paralelamente, não deverá ser menosprezado o peso de um outro factor, a saber, o conhecimento imediato dos textos - clássicos, novilatinos e vernáculos -, que iam sendo editados, com uma progressão exponencial, a partir do começo do século XVI. Um letrado de formação humanista, como António Ferreira, não precisa de viajar pelo estrangeiro para aprender a compor os sonetos, as odes, as elegias, as éclogas, os epitalâmios, as cartas, os epitáfios e os epigramas, que constituem larga parte da sua produção poética. E, com certeza, não é unicamente ao seu mestre reconhecido, e por ele tão admirado, Sá de Miranda, que Ferreira vai buscar a sua inspiração.

Ora, em Portugal, foram precisamente António Ferreira e, em menor medida, Sá de Miranda, os precursores daquele filão de petrarquismo não ortodoxo a que pertenceu André Falcão de Resende, e que, em Itália, foi representado, na forma mais completa e articulada, por Bernardo Tasso.

A partir dos anos 30, de facto, a crise do Renascimento acarreta uma mudança na sensibilidade estética, que reflecte, de perto, uma profunda transformação ideológica. Em certos clássicos latinos, nomeadamente, nas sátiras de Horácio e nas bucólicas de Virgílio, busca-se não apenas um molde métrico-formal, mas antes um conjunto de temas e de valores, que, afastando-se da tradição lírica amorosa de cunho petrarquista, acaba por recuperar uma dimensão mais íntima, e, ao mesmo tempo, mais universal. Aprecia-se, do "bucolismo", o elogio da vida agreste, ou então, o tema de tranquilo retiro, longe dos tumultos da corte e da guerra; ao passo que o "horacianismo" é interpretado, especificamente, como uma atitude ética e um paradigma de equilíbrio, na busca daquela medietas que é, por definição, áurea. 
A poesia faz-se, então, reflexão moral, espelho de eventos quotidianos, evocação de virtudes extintas, conversa demorada com os amigos e, até, canto do amor, preferencialmente conjugal. À diferença dos líricos petrarquistas, amarrados à temática amorosa neo-platónica, bem como a um conjunto de lugares-comuns pré-determinados, são Bernardo Tasso, em Itália, e André Falcão de Resende, em Portugal, os intérpretes, de certa forma exemplares, desta veia secundária, mas persistente, da lírica quinhentista.

Vários traços aproximam os dois poetas: ambos descendem de uma linhagem nobre, desprovida, porém, de recursos, o que os obriga, ao longo de toda a vida, a buscar, por entre muitas dificuldades, meios de sustento para si próprios e para a sua família. À relativa falta de ambição, a não ser no âmbito das letras, vem-se acrescentar o desejo de uma vida sossegada, sem grandes êxitos e sem grandes tumultos. Os afectos familiares e, em particular, o amor da esposa, vêm substituir-se a qualquer protótipo literário da mulher amada. $\mathrm{O}$ estudo e a aplicação às humanae litterae constituem, para ambos, a aspiração máxima, que constantemente se confronta com os estorvos decorrentes das incumbências oficiais. ${ }^{18} \mathrm{E}$, finalmente, os acontecimentos históricos acabam por os arrastar à tão desejada tranquilidade, forçando Bernardo ao desterro, ${ }^{19}$ e obrigando Falcão, já velho, a participar numa empresa militar. ${ }^{20}$

18 Bernardo, como já vimos, foi secretário particular do Príncipe Ferrante Sanseverino, em Nápoles; Falcão exerceu o cargo de Juiz de fora, em Torres Vedras, a partir de 1576.

${ }^{19}$ Em 1547, em virtude do grave dissídio entre o Príncipe de Salerno e o vice-rei de Nápoles, Bernardo teve de abandonar a casa, a família e a Itália, para acompanhar Sanseverino até França, em conformidade com as obrigações de qualquer servidor, que se mantém fiel ao seu senhor, tanto nos bons como nos maus momentos.

${ }^{20}$ Em 1589, acompanhou as forças militares portuguesas na batalha contra os Ingleses, conduzidos por William Blake e pelo Prior do Crato; em 1591, participou, com o filho Luís, na batalha dos Açores, onde a frota inglesa sofreu uma tremenda derrota, com a morte de Sir Richard Grenville, no Revenge. 
Até para a crítica literária moderna, Bernardo Tasso e André Falcão de Resende comungam do mesmo destino: nas histórias da literatura, ambos são relegados a notas de rodapé, ou a parágrafos de corpo menor, de modo a sublinhar, até do ponto de vista tipográfico, a marginalidade que pautou o cunho da sua existência terrena.

Bem diferentes, contudo, são os motivos do desinteresse geral. Cortesão desditoso e esposo infeliz, pela separação forçada da tão amada mulher, Bernardo, apesar da sua imponente produção poética, aliás, integralmente impressa em vida, verá a sua fama ofuscada pelo êxito fulgurante do seu próprio filho, Torquato Tasso, o qual virá a imprimir marcas de uma importante viragem na lírica quinhentista italiana.

Quanto a André Falcão de Resende, nunca verá publicada a sua própria obra: morre, de facto, em 1599, na peste grande que assolou Lisboa, depois de ter composto uma elegia sobre aquele acontecimento, que é transmitida pelo único manuscrito em que se conservam as obras deste autor.

O preciosíssimo códice encontra-se, hoje, nos Reservados da Biblioteca Geral da Universidade de Coimbra, onde tem a cota 1239. Não é, com toda a certeza, autógrafo, como facilmente se deduz, além do mais, da nota final da Epístola Trezena: ${ }^{21}$ mas o anónimo copista, talvez um filho, ou um amigo, de André Falcão de Resende, teve acesso, sem dúvida, aos autógrafos do autor, que recolheu, com toda verosimilhança, em vista da sua publicação, como mais adiante diremos.

Muito se escreveu, desde 1951, acerca do mau estado deste códice: ${ }^{22}$ cumpre-nos, por conseguinte, reduzir às justas proporções o relato das condições do manuscrito, depois

21 «Esta Espistola [sic] tenho duuida ser do Autor mas acheya entre os seus papeis. Esta aspitola [sic] de çima» (ms. 1239, f.118r).

22 Vejam-se, à distância de trinta anos, as palavras do Doutor Ramalho, único compulsador recente do códice: «O ms. está muito deteriorado nas margens, a desfazer-se aos poucos, mas o papel encorpado e a letra legível tornam fácil a leitura das versões de Horácio, por exemplo, cujos versos não atingem a margem esgaçada» (Américo da Costa Ramalho, A edição de Coimbra e os manus- 
de o ter apuradamente manuseado, com vista à edição crítica de André Falcão. Trata-se, pois, de um pequeno volume, com cerca de 20x15 cm., constituído por 178 folhas de papel encorpado (mais oito não numeradas): a brochura moderna protege o códice de danificações ulteriores. A mão do único compilador é muito ordenada e regular, respeitando as normas em vigor nos finais do século XVI. A tinta preta, de boa qualidade, permite uma leitura do texto sem qualquer dificuldade. Faltam, como explicaremos em seu lugar, as folhas iniciais e finais, que foram arrancadas antes de o volume ser encadernado. Além disso, apenas há a lamentar a corrosão das margens, precisamente no começo e no fim do volume, por causa da humidade que nele se infiltrou, em tempos pretéritos. Mas, uma tal circunstância, felizmente, apenas afecta, de entre os textos, aqueles que são copiados em duas colunas, o que raramente acontece, sendo essa disposição utilizada tão só na transcrição dos romances em castelhano e de algumas trovas, os quais não representam, por certo, as melhores páginas da obra de Falcão. Quanto às restantes composições, quer se trate de sonetos, odas, sátiras, ou das oitavas do poema didascálico, encontram-se bem centradas na folha, de tal modo que apenas se perderam, aqui e ali, algumas notas marginais, ou passos das rubricas.

Cabe aqui lembrar, de uma vez por todas, que a escassez da tradição manuscrita não pode ser considerada indício proporcionalmente directo da circulação reduzida de uma obra, nem, tão pouco, da sua menor importância, mas, antes e apenas, de uma difusão limitada dentro de um círculo restrito de pessoas, como era, aliás, normal, no que concerne à lírica de Quinhentos.

critos, [1951] in Id., Estudos sobre a Época do Renascimento, Coimbra 1969 (Lisboa $1997^{2}$ ), p. 210); «Este manuscrito que, há cem anos, se encontrava em muito mau estado, apresenta-se hoje quase desfeito» (Id., Para a edição da obra poética de André Falcão de Resende, in Critique textuelle portugaise. Actes du Colloque (Paris, 20-24 octobre 1981), Paris, Fundação Calouste Gulbekian, 1986, p. 227. 
Pelo contrário, as características do manuscrito das obras de Falcão, tão cuidadosamente organizado e copiado, com as suas secções bem definidas, títulos, subtítulos, títulos correntes, rubricas, dedicatórias, etc., sugerem um plano de edição que, se não foi concebido pelo próprio autor, por ele teria sido, talvez, ideado, nas suas linhas gerais. Certo é que o códice, tal como se nos apresenta, não pode ser considerado um qualquer livro de mão, confeccionado para uso pessoal, mas sim uma colectânea expressamente dedicada à obra de um só autor, tendo em vista a sua publicação.

Quando Falcão morreu, com mais de setenta anos, na peste de Lisboa, tinha acabado de sair dos prelos a edição "princeps" das Rhythmas de Camões (1595): este acontecimento maior da história editorial portuguesa inaugurou, como é bem sabido, a divulgação, pela imprensa, da obra lírica dos poetas quinhentistas, cuja circulação, até à data, apenas corria por via manuscrita.

A singular sorte das rimas, ou seja, da produção especificamente lírica dos poetas quinhentistas portugueses, depende, em larga medida, da presença de uma rígida censura, que exerceu um controlo estrito sobre qualquer tipo de publicação, chegando a influenciar, não raro, o trabalho autoral. ${ }^{23}$

23 A poesia lírica é, por definição, amorosa, e, ademais, naquela época, cheia de alusões à mitologia clássica: amor profano e mitos pagãos bastavam largamente para despertar o interesse dos censores. Assim se faz com que as poesias líricas dos maiores poetas portugueses da época só viram ao prelo (se é que viram) no fim do século XVI, ou até em começos do século XVII. Além disso, vários exemplos aclarados mostram como a censura influenciou a própria criação poética, quer ocasionando, não raro, duplas redacções de autor, quer sugerindo formas pontuais de auto-censura, ou censura preventiva. Sobre o assunto, cf. Israel Salvador Révah, La censure inquisitoriale portugaise au XVIe siècle, Lisboa 1960; Graça Almeida Rodrigues, Breve história da censura literária em Portugal, Lisboa, 1980; J.-M. De Bujanda, L'exercice de la censure de l'Inquisition portugaise au XVIe siècle, in Le contrôle des idées à la Renaissance, éd. par J.-M. De Bujanda, Genève, Droz, 1996, pp.153-171; B. Spaggiari, La censure dans la transmission de l'oeuvre de Luís de Camões, in Censure et Littérature dans les pays de langues romanes, 
Não temos por inútil uma chamada de atenção para as datas e os nomes em jogo: aparentemente sob o impulso (e a tutela) da "princeps" camoniana, no mesmo ano de 1595, e batidas pelo mesmo editor, Manoel de Lyra, saíram as Poesias de Francisco Sá de Miranda. Logo de seguida, em 1596 e em 1597, respectivamente, foram editatos póstumos o Lima e as Rimas Várias. Flores do Lima de Diogo Bernardes, que, em vida, apenas vira impressas, em 1594, as Rimas Várias ao Bom Jesus, ou seja, a poesia ao divino. Em 1598, são dados ao prelo, graças aos cuidados do filho, os Poemas Lusitanos de António Ferreira, falecido já há vinte anos.

Pode-se afirmar, portanto, que a produção lírica quinhentista portuguesa permaneceu inédita, no sentido em que a sua transmissão se viu limitada à via manuscrita até finais do século XVI, momento em que, no decurso de poucos anos (precisamente, de 1595 a 1598), saíram à luz as rimas de Miranda, Ferreira, Camões, Bernardes, ou seja, de todos os poetas maiores.

Logo no começo do século XVII, foi impressa a poesia de Baltasar Estaço (1604) e de D. Manoel de Portugal (1605), ao passo que Pero de Andrade Caminha ficou inédito até 1791, continuando a faltar, ainda hoje, como dissemos, uma edição, de qualquer tipo que seja, para André Falcão de Resende.

É já tanto, então, que de Falcão se conserve, apesar de mútilo, aquele apógrafo a que anteriormente aludimos. A história do seu casual descobrimento, que foi diligentemente relatada por Américo da Costa Ramalho, quase parece decorrer do anedótico ${ }^{24}$. Não fosse o facto de possuirmos documentos

Actes du Colloque org. par l'équipe ERILAR (Rennes, 13-14 mars 1998). Textes réunis et présentés par Claude Le Bigot et Yves Panafieu, Rennes, Presses de l’Université, 2000, pp.101-109.

${ }^{24}$ Cf. Ramalho, Para a edição..., cit. p. 227: «Foi encontrado em 5 de Janeiro de 1800 por um homem chamado Tomé Luís Felgueiras que o trocou por igual quantidade de papel novo, quando o ajudante do boticário da Misericórdia de Guimarães começou a arrancar-lhe as folhas para fazer cartuchos para pílulas». 
autógrafos, e, além disso, de terem chegado até nós as reiteradas asserções do descobridor do códice, seria justificada a sensação de estarmos perante uma variante moderna daquele topos clássico e humanístico, em que um livro, mesmo ilustre, acaba por ser utilizado pelo vendedor de bacalhau para embrulhar peixe. O próprio Bembo, de acordo com uma lenda que, em tempos passados, granjeou notável crédito, teria descoberto num açougueiro as folhas do autógrafo de Petrarca, que depois desfrutou para a edição aldina de $1501 .{ }^{25}$

A casualidade, aliás, domina a sorte da poesia quinhentista portuguesa, como escrevia, há um século, D. Carolina. ${ }^{26}$ O único manuscrito que nos transmite a obra de Falcão, a julgar pelas suas características, destinar-se-ia à publicação, como já dissemos, no âmbito daquele movimento editorial que levou à impressão, nos últimos anos do séc. XVI, das rimas de outros líricos quinhentistas. Mas, em virtude de causas que ignoramos, não veio à luz por essa ocasião. Bem pelo contrário, o códice desapareceu até 1800, data do seu fortuito descobrimento, naquela farmácia do Minho.

Desta feita, é com dois séculos de atraso que a suspirada edição parece, enfim, realizar-se, graças aos cuidados de Joaquim Inácio de Freitas, antigo revisor da Imprensa da Universidade de Coimbra. Com suma diligência, é ele quem copia o apógrafo na íntegra, acrescentando, no começo e no fim, toda a documentação que pôde recolher sobre Falcão, inclusive sobre a sua vida.

25 Cf. Michele Feo, Tradizione latina, in Letteratura Italiana Einaudi, Torino, 1986, vol. V, pp. 311-378 (nomeadamente, o parágrafo 7, pp.357-365).

26 Cf. Carolina Michaëlis de Vasconcelos, O cancioneiro do Padre Pedro Ribeiro, Coimbra, 1924, pp. 47-48 : "A incúria dos homens e a fatalidade exerceram, como é sabido, terríveis depredações na poesia portuguesa da segunda metade do século XVI e dos primeiros anos do século XVII. Enquanto decerto proliferavam os cancioneiros de mão [...], poucos poetas cuidavam de reunir e acepilhar as suas obras no sentido de as darem à estampa, de modo a salvar assim as suas criações da precaridade dos manuscritos e da contingência das edições póstumas organizadas por outrem». 
Desta vez, acrescido de dados biográficos e relatos documentados, o chamado MS. do Sr. Freitas, que hoje se conserva, juntamente com o apógrafo quinhentista, nos reservados da Biblioteca Geral de Coimbra (cota 1238), está, finalmente, pronto para publicação, como se pode ler na pág.4: «pode imprimir-se excepto as notas, e o que se acha escrito em espanhol». A cópia do Sr. Freitas traz a data de 1801: o tal despacho, correspondente à licença obtida, nos mesmos termos, pela censura, é datado de 20 de Março de 1829. ${ }^{27}$ Quase trinta anos decorreram, portanto, até que o manuscrito entrasse no prelo.

Mais uma vez havia de ficar interrompida, porém, a empresa editorial, em virtude do falecimento do seu organizador; ${ }^{28}$ só decorridos vários anos, será dado início, da mesma feita no âmbito da Imprensa da Universidade, à impressão do inédito, sob a direcção de uma comissão. O malfadado manuscrito do Sr.Freitas, revisto e parcialmente anotado pelo novo organizador, que assina as suas intervenções como Editor (sem mais), acaba por entrar em impressão, tendo-se chegado a segundas provas. Contudo, o falecimento de um dos membros da comissão, talvez Joaquim Urbano de Sampaio, ${ }^{29}$ notável pelos seus conhecimentos filológicos, deixou o trabalho inacabado e "sem esperança de conclusão».

Quando Inocêncio escreveu essa anotação, em 1858, não teria imaginado quão certa era a sua profecia. De facto, a edição coimbrã da obra de André Falcão de Resende nunca veio a lume: inacabada, ou mesmo gorada, como bem a define o Senhor Doutor Ramalho, não passou da fase de provas tipográficas, ainda incompletas, que chegaram apenas a ser corrigidas.

27 Cf. Ramalho, Para a edição..., cit., p. 227.

28 O Sr. Freitas morreu no mês de Fevereiro de 1831, conforme relatam Inocêncio e Esteves Pereira - Guilherme Rodrigues no seu Portugal, Dicionário Histórico etc. (veja-se, também, Ramalho, Estudos..., cit., p. 286 e Para a edição..., cit., p. 227).

${ }^{29}$ Morreu, de facto, em 1852. 
Mesmo desta forma precária, alguns exemplares do conjunto das provas acabaram, contudo, por ir circulando, entre especialistas ou bibliófilos da segunda metade do século XIX. Vários testemunhos independentes, naquela roda de anos, aludem aos poemas de André Falcão, quer baseando-se em referências ouvidas a outrem, quer fundando-se num conhecimento directo dos textos. Todos ficam, porém, na incerteza, pelo que diz respeito aos dados bibliográficos fundamentais: a data de publicação, o título do volume inacabado, o seu conteúdo final, o(s) nome(s) de seu(s) organizador(es). A falta de referências exactas de modo algum será estranha, pois o material da Imprensa da Universidade de Coimbra era desprovido da página de rosto, bem como de qualquer informação sobre o autor, das notas que deviam vir no fim do volume, e do prefácio. A maioria dos exemplares começava, de facto, pelo poema didascálico intitulado Microcosmographia, interrompendo-se logo no início da secção dedicada às Glosas e romances em castelhano. ${ }^{30}$

Por essas mesmas razões, o volume vai sendo fortuitamente referenciado, sob o título de Poesias ou Obras de André Falcão de Resende, com oscilações muito amplas quanto à data de edição: 1859 (Fidelino de Figueiredo), 1860 (Visconde de Juromenha, Carolina Michaëlis), 1861 (a mesma D. Carolina), 1862 (Wilhelm Storck), 1865 (Aubrey Bell), 1881 (Jorge de Sena). ${ }^{31}$

Ora, na secção dos Reservados da Biblioteca Geral da Universidade de Coimbra, que guarda larga parte dos materiais necessários à edição crítica de André Falcão de Resende, encontra-se a resposta definitiva, pelo que diz respeito à data dessa edição inacabada. Com efeito, alargando a pesquisa

${ }^{30}$ A versão mais comum das provas conta 480 páginas, no total. Não falta, aliás, testemunha duma versão mais comprida, que continha 496 páginas, incluindo mais 16 páginas preenchidas com versos em espanhol, segundo afirma Ramalho, Para a edição..., cit., p. 232.

31 Muito prudentemente, a história da literatura de Saraiva-Lopes limita-se a propor uma data «antes de 1867». 
ao acervo, ainda por ordenar, dos «Documentos sobre a Imprensa da Universidade», no Inventário dos Armazens da Imprensa 1861-1862 (Inv. n. ${ }^{\circ}$ 678), encontrámos o único vestígio certo da projectada edição:

«Resende (A. Falcão) - Poesias - (por acabar) 30 Junho de 1861»

No mesmo inventário, passado um ano, a 30 de Junho de 1862, já não aparece o nome de Falcão, ao lado dos seus mais afamados antecessores, Garcia de Resende e L. André de Resende, dos quais ainda estavam disponíveis, respectivamente, a Chronica d'ElRey D. João 2. ${ }^{\circ}$ e o livro $D e$ Antiquitatibus Lusitaniae.

Impõe-se a conclusão de que a edição inacabada de Falcão, sob forma de segundas provas em cadernos soltos, se encontrava nos armazéns da Imprensa a 30 de Junho de 1861, data em que foi fechado o relativo Inventário. Os poucos exemplares existentes da tiragem saíram para venda, de modo mais ou menos oficial, nesse mesmo ano de 1861, ou no começo de 1862. Daí advêm todas as referências que, de então até hoje, lhes têm vindo a ser feitas, e o breve momento de glória que Falcão alcançou, no século XIX, muito deve à publicação avulsa de alguns dos seus poemas, ora tendo em vista a edição inacabada, ${ }^{32}$ ora em tácita concorrência com ela. ${ }^{33}$

32 É o caso, por exemplo, da Ode a Martim de Castro do Rio, senhor de Barbacena etc., dada à luz por Joaquim Inácio de Freitas como amostra da edição que se propunha fazer, num fascículo de 8 páginas editado pela Imprensa da Universidade (Coimbra, 1823). Cf. Inocêncio, IV, 1860, p.87.

33 O mesmo Inocêncio (VIII, 1867, p. 62) assinala a publicação de algumas odas inéditas de Falcão, quer de autoria do próprio poeta, quer traduzidas de Horácio, em vários números do jornal lisboeta O Interessante, durante o ano de 1832. O maior interesse da publicação avulsa reside no facto de que a fonte declarada era um outro manuscrito, que estava na posse do redactor Joaquim José Pedro Lopes. Este testemunho oitocentista será tido em linha de conta na edição crítica em preparação. 
A curiosidade despertada por André Falcão, naquela altura, privilegiava essencialmente a sua faceta de observador informado, ou, então, o seu talento de tradutor. Além do poema didascálico, que circulou, em época mais remota, sob autoria camoniana, ${ }^{34}$ os textos de Falcão que obtiveram maior sucesso foram, sem dúvida, o seu romance com o relato dos acontecimentos do ano 1591, a saber, a batalha naval da Ilha Terceira, ${ }^{35}$ e uma carta em prosa que contém a crónica pormenorizada da vinda dos Ingleses a Lisboa, em 1589. ${ }^{36}$.

Testemunha ocular de eventos militares, nos anos da própria velhice, Falcão exerce, sem alento, o ingrato papel de

34 A “editio princeps" da Microcosmographia saiu em 1615 (e não em 1616, conforme o afirmam muitos críticos): cf. OBRA/DO GRANDE LUIS/DE CAMÕES, Prin-/CIPE DA POesia/Heroyca. Da creação, E composição do Ho-/mem. Com as Licenças necessarias./Em Lisboa, por Pedro Crasbeeck./ANNO 1615. O poema didascálico foi reimpresso pela mesma editora em 1616, juntamente com as Rimas de Luís de Camões. Segunda parte (...) por Domingos Fernandes (Lisboa. Na oficina de P. Craesbeeck). O destinatário desta edição, D. Rodrigo da Cunha, foi o primeiro a contestar a sua autenticidade. Daí em diante, a tradição impressa dividiu-se; por um lado, os editores mais escrupulosos retiraram o poema das obras de Camões, declarando-o espúrio (Faria e Sousa, 1685; edição de Hamburgo, 1834). Por outro lado, mesmo negando a autoria camoniana, os demais continuaram a publicá-lo, para assegurar o carácter completo da própria edição da "opera omnia" atribuída a Luís de Camões (cf., por exemplo, a edição de Paris de 1815, onde o poema figura no t. V, p.279 ss.).

35 O Romance do sucesso da Armada que foy às ilhas Terceiras no ano de 1591 foi publicado duas vezes: em 1885, no "Archivo dos Açores», por iniciativa de Ernesto de Canto; e, cinco anos depois, no Catálogo razonado biográfico y bibliográfico de los autores portugueses que escribieron en castellano, por Domingo Garcia Peres (Madrid, 1890, pp.190-202). Novamente editado, em 1975, por Costa Ramalho, no tomo XVI das Memórias da Academia das Ciências de Lisboa - Classe de Letras, dele existe também uma reimpressão recente no volume Estudos sobre o século XVI, acima citado, [XVII. O último combate de Sir Richard Grenville, pp. 261-284, 293-294], que reúne vários artigos do Senhor Doutor Ramalho.

36 A Carta que o Autor escreveu a um seu Amigo em que conta a vinda dos Ingreses a Lisboa com D.António Prior do Crato no ano de mil e quinhentos e oitenta e nove saiu, pela primeira vez, em trascrição diplomática, no «Archivo Bibliographico da Universidade de Coimbra» I (1901). 
cronista de guerra, em verso e em prosa. As dezenas e dezenas de versos, em que descreve acontecimentos nos quais participou pessoalmente, representam mais uma faceta da sua actividade, susceptível de despertar o nosso interesse, apesar do seu escasso valor poético. Na verdade, a sua Musa solitária e discreta, impregnada de meiguice, acomoda-se com dificuldade ao tom triunfal com que tem de celebrar vitórias que, afinal, não resgatam o país da dominação espanhola.

Superior é o êxito das traduções horacianas, já que entre o poeta e o seu predecessor latino se estabelece uma perfeita consonância de sentimentos e valores morais. Neste sentido, mais do que um modelo poético, Horácio torna-se um verdadeiro referente arquetípico, na medida em que, não apenas oferece esquemas compositivos, mas representa também as qualidades humanas e literárias a que o nosso poeta aspira. A sua empresa de tradutor, com mais de 30 odes, coloca-o num lugar de primeiro plano dentro do "horacianismo" ibérico, como já reconheceu Menéndez y Pelayo.

No ritmo lento e envolvente das odes, ou na cadência sossegada das sátiras, Falcão atinge o mais alto nível da sua experiência poética, quer como tradutor de Horácio, quer como autor de versos que de forma alguma desmerecem, no quadro geral da poesia quinhentista portuguesa.

Convirá, aliás, sublinhar que a obra de Falcão tem dimensões importantes. Dela nos transmite, o apógrafo quinhentista, em primeiro lugar, os três cantos do poema Da creação do homem (207 oitavas), acompanhados por várias composições dedicatórias e laudativas. Segue-se a secção de composições dedicadas a D. Joana Loba, sob o título geral de Epithalamio; duas glosas em oitavas a outros tantos sonetos; a égloga Alcino, Luso, Feliso; sucessivamente, até à f. 60v, a maior secção, a dos sonetos (82). Na restante parte do códice, encontram-se duas sextinas, quarenta odas, oito sátiras, seis epístolas, vinte trovas, quinze poemas vários (entre os quais ganham relevo uma elegia, uma égloga, um epigrama), os 
intermináveis romances em castelhano, alguns versos latinos de boa feitura, a Elegia sobre a peste (de que o próprio poeta havia de morrer) e a carta em prosa sobre o Prior do Crato. ${ }^{37}$

Como vimos, na esteira de Sá de Miranda e de António Ferreira, André Falcão de Resende experimenta com mestria todos os moldes poéticos da medida nova, inclusive a oda em forma de lira, mas sem descurar as trovas, as cantigas tradicionais, ou os romances em redondilha.

Apesar dessa receptividade às novas formas poéticas, Falcão mostra, porém, ignorar, programaticamente, a canção de cunho petrarquista, cuja ausência poderá, talvez, ser interpretada como o mais vistoso sinal de um alinhamento por aquela vertente de um petrarquismo não ortodoxo a que anteriormente aludimos.

A poética de Falcão, com efeito, exclui alguns dos traços pertinentes daquele petrarquismo que se viera formando a partir do modelo trecentista, a saber: a partição das rimas 'em vida' e 'em morte'; o amor platónico dedicado a uma mulher que permanece, por definição, inatingível; e, sobretudo, a 'forma-canzoniere'. Em consonância, aliás, com as tendências que se afirmaram a partir de meados do século XVI, a obra de Falcão apresenta-se mais como um 'livro de rimas', do que como um 'canzoniere' no sentido petrarquista do termo, isto é, uma recolha organizada e estruturada em todas as suas partes, segundo uma arquitectura bem precisa, cunhada pelo próprio autor.

O 'livro de rimas' quinhentista, ao contrário do 'canzoniere', é composto por segmentos modulares, que se organizam de modo horizontal e paratáctico, à falta de um centro polarizador. Com efeito, pode-se reconhecer, no 'livro de rimas', a mesma tendência para agrupar os poemas segundo formas e géneros, que constitui a característica dominante

${ }^{37}$ A edição crítica em preparação terá também em linha de conta as poucas peças avulsas publicadas em vida do poeta. 
das recolhas impressas, antológicas e miscelâneas, já que, neste caso, não é o autor, mas a forma poética (seja essa o soneto, a elegia, ou qualquer outra) o elemento estruturante.

Um outro aspecto caracteriza André Falcão como representante típico da poesia da segunda metade do século XVI: o plurilinguismo. Provido de uma boa técnica versificatória, que lhe permite manusear o decassílabo italiano a par da redondilha autóctone, Falcão é também capaz de compor, indiferentemente, em português, em castelhano, em latim, com algumas incursões no domínio do italiano e do francês, confinadas a versos isolados de poemas.

Na sequência do que acabamos de constatar, André Falcão de Resende merece ser conhecido pelo menos enquanto representante, em área lusitana, daquela preciosa e esquiva corrente classicista, que sobrevive ao lado do petrarquismo dominante, enquanto sua silenciosa alternativa.

Depois de ter percorrido a obra de André Falcão, e apesar dos seus êxitos desiguais, a que aludimos, o leitor dificilmente poderá ficar insensível ao subtil fascínio da sua $\mathrm{voz}$ submissa, da tonalidade humilde, da resignada melancolia e da meiga tristeza, que emanam dos seus versos. 